\title{
AHS ve MAUT Yöntemi ile En İdeal Hizmet Kalitesi Kriterlerine Sahip Olan İşletmenin Belirlenmesi: Ordu İlindeki Oteller Üzerinde Bir Araştırma
} (Determination of the Establishment with the Most Ideal Service Quality Criteria by AHP and MAUT Method: A Research on Ordu Hotels)

\section{Hakan AKYURT ${ }^{\text {iD }}$ a Şerif Ahmet DEMIRDAĞ}

a Giresun Üniversitesi, Bulancak Kadir Karabaş Uygulamalı Bilimler Yüksekokulu, Turizm İşletmeciliği ve Otelcilik Bölümü, Giresun, Türkiye. hakan.akyurt@giresun.edu.tr

b Giresun Üniversitesi, Bulancak Kadir Karabaş Uygulamalı Bilimler Yüksekokulu, Turizm İşletmeciliği ve Otelcilik Bölümü, Giresun, Türkiye. serif.demirdag@giresun.edu.tr

\begin{tabular}{|c|c|}
\hline MAKALE BİLGİSİ & ÖZET \\
\hline $\begin{array}{l}\text { Otel İşletmeleri } \\
\text { Hizmet Kalitesi } \\
\text { AHS } \\
\text { MAUT }\end{array}$ & $\begin{array}{l}\text { Amaç - Bu araştırmanın amacı, otel işletmeleri yöneticilerinin algılarında hangi hizmet kalitesi } \\
\text { kriterinin önemli olduğunu ortaya koymalarını sağlamak ve bu kriterlerin işletme açısından önem } \\
\text { derecesini belirlemektir. Bu doğrultuda çalışma, turizm talebi üzerinde oldukç̧a etkili olan hizmet } \\
\text { kalitesi kriterleri hakkında otel işletmesi yöneticilerinin faydalanabileceği bilgiler sunacağı } \\
\text { konusunda önem taşımaktadır. Ayrıca yöneticiler, işletme maliyetlerinin düşürülmesinde, } \\
\text { turistlerin istek ve ihtiyaçlarına uygun hizmet kalitesi kriter seçiminde önemli bir rekabet avantajı } \\
\text { da elde edebileceklerdir. Araştırma sonuçlarının katılımcı otel işletmeleri ile paylaşılarak, } \\
\text { işletmelerdeki mevcut hizmet kalitesi kriterlerinin iyileştirilmesi ve geliştirilmesi konusunda katkı } \\
\text { sağlanması amaçlanmaktadır. }\end{array}$ \\
\hline $\begin{array}{l}2019 \\
\text { Revizyon Tarihi } 2 \text { Aralık } 2019 \\
\text { Kabul Tarihi } 15 \text { Aralık } 2019\end{array}$ & $\begin{array}{l}\text { Yöntem - Araştırmada Analitik Hiyerarşi Süreci (AHS) ile MAUT tekniği kullanılmıştır. Bu iki } \\
\text { yöntem Çok Kriterli Karar Verme (ÇKKV) yöntemlerinden olup, hem hizmet kalitesi kriterlerinin } \\
\text { önem derecesine göre sıralanması hem de en ideal hizmet kalitesi sunan otel işletmesinin tespit } \\
\text { edilmesi amacıyla uygulanmıştır. Hizmet kalitesi kriterlerinden hangilerinin daha önemli olduğu } \\
\text { uzman görüşleri alınarak belirlenmiştir. }\end{array}$ \\
\hline $\begin{array}{l}\text { Makale Kategorisi: } \\
\text { Araştırma Makalesi }\end{array}$ & $\begin{array}{l}\text { Bulgular - Araştırma sonucunda AHS tekniği ile elde edilen verilerde, hizmet kalitesinin on kriteri } \\
\text { arasında en önemli kriterin "temizlik" kriteri olduğu belirlenmiştir. Bununla birlikte diğer en önemli } \\
\text { kriterler "nezaket ve saygı, güvenirlilik, işlem ve erişim kolaylığı" olarak tespit edilmiştir. Bu } \\
\text { kriterlere göre en ideal hizmet kalitesi sunan otel işletmesinin hangisi olduğu MAUT tekniği ile elde } \\
\text { edilen analiz bulguları sonucunda gösterilmiştir. }\end{array}$ \\
\hline & $\begin{array}{l}\text { Tartışma - Ordu ili içerisinde faaliyette bulunan dört ve beş yıldızlı otellerin yöneticilerinin } \\
\text { algılarında temizlik unsurunun en önemli hizmet kalitesi kriteri olduğu belirlenmiştir. Bu sonuçtan, } \\
\text { turistlerin bir otelin hizmet kalite standartları algılarında otelin temizliğinin ilk dikkat çeken husus } \\
\text { olduğu sonucuna ulaşmak mümkündür. Kat hizmetleri, ön büro ve restoran hizmetlerinin otel } \\
\text { yöneticileri tarafından hizmet kalitesinin sunumunda arka sıralarda yer aldığı belirlenmiştir. }\end{array}$ \\
\hline
\end{tabular}

\begin{tabular}{|c|c|}
\hline ARTICLE INFO & ABSTRACT \\
\hline Keywords: & $\begin{array}{l}\text { Purpose - The purpose of this research is to determine which service quality criteria are important } \\
\text { for hotel managers' perceptions and to determine the importance of these criteria for the hotel }\end{array}$ \\
\hline Hotel Establishments & establishments. In this respect, the research is important that the hotel management could provide \\
\hline Service Quality & information about service quality criteria which are very effective on tourism demand. In addition, \\
\hline AHP & the managers will be able to obtain a significant competitive advantage in reducing operational costs \\
\hline MAUT & $\begin{array}{l}\text { and selecting appropriate service quality criteria to the needs and desires of tourists. It is also aimed } \\
\text { to contribute to the improvement of the existing service quality criteria in hotel establishments by } \\
\text { sharing the results of the research. }\end{array}$ \\
\hline Received 30 September 2019 & Design/methodology/approach - Analytical Hierarchy Process (AHP) and MAUT technique were \\
\hline Revised 2 December 2019 & used in the research. These two methods, which are multi-criteria decision-making methods, have \\
\hline Accepted 15 December 2019 & $\begin{array}{l}\text { been applied both in order to rank the quality of service criteria according to their importance and } \\
\text { to determine the hotel service offering the most ideal service quality. The service quality criteria } \\
\text { which is more important was determined by taking expert opinions. }\end{array}$ \\
\hline
\end{tabular}

\section{Önerilen Atıf/ Suggested Citation}

Akyurt, H., Demirdă̆, Ş. A.(2019) AHS ve MAUT Yöntemi ile En İdeal Hizmet Kalitesi Kriterlerine Sahip Olan İşletmenin Belirlenmesi: Ordu İlindeki Oteller Üzerinde Bir Araştırma , İ̧sletme Araştırmaları Dergisi, 11 (4), 3131-3142. 
Findings - As a result of the research, it was determined that the most important criterion among the ten criteria of service quality was the "cleaning" criterion in the data obtained with AHP technique. However, the other most important criteria are "kindness and respect, reliability, ease of operation and access". According to these criteria, the results of the analysis obtained by MAUT technique have been shown which hotel business offers the most ideal service quality.

Discussion - It is determined that cleaning is the most important service quality criterion in the perceptions of four- and five-star hotel managers operating in Ordu. According to this result, it is possible to conclude that the cleanliness of the hotel is the first thing that attracts attention in the perception of the service quality standards of a hotel. It was determined that housekeeping, front desk and restaurant services are in the back row in the presentation of service quality by hotel managers.

\section{GİRİ̧}

Kâr amacı güden her işletme türünde olduğu gibi, turizm sektöründe otel işletmelerinin amacı da tüketicilerin tatmin olmasını sağlayarak, tüketici sadakati ve bağlılığı oluşturmaktır. Sunulan hizmetlerden tatmin olarak ayrılan tüketiciler, bir dahaki satın alma sürecinde tekrar aynı işletmeyi tercih edecek ya da kulaktan kulağa reklam ile diğer potansiyel tüketicileri etkileyebilecektir. Bu durum, işletmelerin kâr ederek varlıklarını sürdürebilmesi konusunda önemli avantajlar sağlamaktadır. Turizm sektöründe sunulan mal ve hizmetlerin ikamesi yüksek olduğundan ve dolayısıyla rekabet ortamının yoğun olmasından kaynaklı olarak tüketicileri elde tutmak işletmeler açısından oldukça önemlidir. Bunun yolu ise tüketicilere kaliteli ve nitelikli hizmet sunmaktan geçmektedir. Birbirinden farklılık gösteren ve sürekli değişen müşteri istek ve ihtiyaçları karşısında aynı düzeyde hizmet sunmak ve hizmetleri standartlaştırmak oldukça güç bir durumdur. Ancak, söz konusu durum her ne kadar güç olsa da işletmeler sundukları hizmetin kalitesini artırarak farklılaşma yoluna gitmeli ve böylelikle mevcut müşterilerini korumaya ve yeni müşteriler (Güçer vd., 2017: 455-456) kazanmaya çalışmalıdır.

Otelcilik sektöründe var olan toplam kalite yönetimi trendi, otel işletmelerinin rekabet avantajı elde etmesini sağlar ve bu nedenle turizm sektöründe hizmet kalitesi kavramı çağdaş araştırma konularından birisi haline gelmiştir (Gržinić, 2007: 81). Soyut bir nitelik taşıması ve kişiden kişiye farklı anlamlar taşıması nedeniyle hizmet ve kalite kavramlarının tanımlanması oldukça güçtür. Hizmet, insanlar ya da makineler aracılığıyla üretilen (Üzerem, 1997: 34), tüketicilerinin ihtiyaçlarını karşılamak amacıyla (Kuriloff ve Hemphill, 1988) somut olmayan faaliyet ya da faydalar (Karafakığlu, 1998: 14) şeklinde tanımlanmaktadır. Diğer bir ifadeyle hizmet, somut bir nitelik taşımayan, elle tutulmaz gözle görülmez, insan ya da makineler tarafından üretilebilen ve kullanan tarafa fayda sağlayan faaliyetlerdir (Güçer vd., 2017: 456). Öncelerden Yunan yazarlar tarafından mahiyet ya da nitelik anlamlarında kullanılmış olup, Latincede "qualitas" sözcügünden türetilmiş olan kalite kavramı ise hem soyut bir fikri hem de somut bir kavramı içinde barındırmaktadır (Halis, 2010:3). Kalite, mal ya da hizmetlerin sunulduğu tüketicilerin ürünler hakkındaki düşünceleri olup, ihtiyaçların ve beklentilerin ihtiyaçların karşılanmasına yönelik inançlarının ölçüsünü ifade etmektedir (Tavmergen, 2002: 126). Kalite, hizmet sektörü açısından düşünüldüğünde ise anlaşılması, uygulanması, kontrol edilmesi ve sürdürülebilirliği oldukça karmaşık, güç ve belirsiz bir yapı olarak görülmektedir (Kılıç ve Eleren, 2009: 92). Oral (1999)'a göre turizm sektöründe hizmet sunan işletmeler için kalite, mevcut veya potansiyel turist ihtiyaçlarını karşılaması beklenen mal ve hizmetleri üretilmek, işletme verimliliğinin arttırmak ve maliyet kontrolleri yapılarak işletme maliyetlerinin azaltılması için kullanılan önemli bir araçtır. Diğer bir bakış açısıyla turizm işletmelerinde kalite, tüketicilerin ihtiyaçlarını karşılama ve onları memnun etmedir (Halis vd., 2010: 39).

Hizmetlerin soyut, değişken, dayanıksız ve heterojen olması, üretiminin ve tüketiminin aynı zamanda olması gibi temel özellikler, hizmetlerin üretimini, satışını, tüketicilerin kalite konusundaki algılarını ve tatmin düzeylerini etkilemektedir. Ayrıca hizmetin soyut özelliğinden dolayı, tüketicilerin hizmetleri satın almadan ya da kullanmadan önce hizmetlerin kalitesi hakkında görüş bildirmeleri mümkün olmamaktadır (Devebakan ve Aksaraylı, 2003: 40). Oysa, hizmet kalitesinin ölçülebiliyor olması işletmeler açısından oldukça önemlidir. Çünkü, sunulan hizmetin kalitesi ölçülemiyor ise kalitenin artırılması, iyileştirilmesi ya da yönetilmesi söz konusu olamaz (Halis vd., 2010: 43). Turizm işletmelerinde hizmet kalitesinin ölçümünde "SERVQUAL", "Lodgserv", "Dineserv", "SERVPERF", "Toplam Kalite Endeksi", “Kritik Olay Yönetimi", “Hizmet Barometresi", "Bazı İstatistiksel Yöntemler" ve "Diğer Yöntemler" olmak üzere farklı yöntemler kullanılabilmektedir (Eleren vd., 2007: 78). Tüketiciler, hizmetlerin kalitesinden doğrudan doğruya 
etkileneceği için sunulan hizmetlerin kalitesi belirli yöntemler kullanılarak tespit edilmelidir (Parasuraman vd., 1985: 42). Diğer bir ifade ile hizmet kalitesi, tüketici beklentilerinin karşılaması üzerine en mükemmel hizmet sunumudur (Okumuş ve Duygun, 2008: 19). Hernon ve Nitecki (2001: 690)'ye göre hizmet kalitesi, "mükemmellik (excellence)", "değer (value)", "özelliklerine uygunluk (conformance to specifications)" ve "beklentilerin karşılanması ve/veya üstünde tutulması (meeting and/or exceeding expectations)" terimlerini içeren en az dört bakış açısıyla tanımlanmaktadır. Hizmet kalitesi, müşterinin her düzeyde (iç ve dış) toplam tatminini sağlamak için iş süreçlerini yönetmenin önemli bir yoludur (Grzinic, 2007: 82). Diğer bir tanıma göre hizmet kalitesi kavramı, tüketicilerin hizmetleri satın aldıktan ya da kullandıktan sonra o hizmetin bireylerde ortaya çıkardığı duygular olup, hizmetlerden hangi düzeyde tatmin olduklarını göstermektedir (Çiçek ve Doğan, 2009: 203). Hizmet kalitesinin tüketiciler tarafından değerlendirmesi, algılanan hizmetin kalitesi ile beklenen hizmet kalitesinin karşılaştırılması sonucunda belirlenmektedir ve ikisi arasındaki fark ise,

\section{“HIZZMET KALİTESİ = Algılanan Hizmet Kalitesi - Beklenen Hizmet Kalitesi”}

formülü ile ifade edilebilir. Bu durumda, hizmet kalitesinin sıfıra (0) eşit olması veya sıfırdan büyük bir değer alması, hizmet kalitesi pozitif olarak değerlendirilmesini ve tüketicilerin tatmininin sağlanmasını; negatif değer alması ise hizmet kalitesi algısının olumsuz olarak değerlendirilmesini ve tüketicilerin tatmininin sağlanmamış olduğunu ifade etmektedir (Aksoy, 2005: 93-94).

Daha önce değinildiği üzere, hizmet kalitesinin ölçülmesine yönelik yapılan araştırmalarda pek çok yöntem kullanılmış olup, hizmet kalitesi farkı boyutlarda ele alınmaya çalışılmıştır. Dolayısıyla, hizmet kalitesi çok boyutlu bir olgudur. Hizmet kalitesi boyutlarından en bilinen ve genel olarak hizmet sunan işletmelerde yoğun olarak kullanılan beş boyutu (Hevesli olmak, güvenilirlik, empati fiziksel özellikler ve güven) Parasuraman, Zeithaml ve Berry (1988) tarafından ortaya atılmıştır (Parasuraman vd., 1988; Zeithaml vd.1990: 176; Devebakan ve Aksarayll, 2003: 41; Güçer vd., 2017: 457);

- Fiziksel Özellikler Boyutu: Hizmet sunmada işletmelerin araç-gereçleri, fiziksel olanakları ve çalışanlarıdır.

- Güvenilirlik Boyutu: Hizmetlerin işletmeler tarafından vaat edildiği şekilde tutarlı, doğru ve güvenilir bir şekilde yerine getirilmesidir.

- Hevesli Olma Boyutu Tüketicilere yardım etmek, tam zamanında açık, hızlı ve doğru olarak taleplere karşılık verme becerisidir.

- Güven Boyutu: Hizmetlerin sunulduğu işletmelerde çalışan personelin, güven, bilgi ve nezaket sunma konusundaki becerisini ifade etmektedir.

- Empati Boyutu: İşletme çalışanlarının ve yöneticilerinin kendilerini tüketicilerin yerine koyabilmesi ve bu şekilde tüketicilerin isteklerine ve ihtiyaçlarına karşı onlara kişisel ilgi ve de alaka gösterebilme becerileri olarak tanımlanmaktadır.

Özellikle hizmet sektörü başta olmak üzere işletmeler açısından hayati önem taşıyan hizmet kalitesi ile ilgili yukarıda yer alan bilgiler ışığında bu araştırmanın amacını, otel işletmeleri yöneticilerinin algılarında hangi hizmet kalitesi kriterinin önemli olduğunu ortaya koymak ve böylelikle bu kriterlerin işletme açısından önem derecesini belirlemek oluşturmaktadır. Söz konusu amaç doğrultusunda, otel işletmelerinin hizmet kalitesini belirlemek ve önem derecesine göre sıralamak üzere belirli kriterler belirlenmiştir. Hizmet kalitesi kriterleri belirlenirken Güven ve Çelik (2007) ile Korucuk vd. (2016)'nin yapmış olduğu çalışmalardan yararlanılmış; ayrıca Sanayi ve Ticaret Odası yetkilileri ve otel yöneticileri ile görüşülmüştür. Edinilen bilgiler doğrultusunda araştırmada kullanılmak üzere hizmet kalitesi ana kriterleri "fiyat (K1)", "güvenilirlik (K2)", "kat hizmetleri kalitesi (K3)", "önbüro hizmet kalitesi (K4)", "restoran hizmet kalitesi (K5)", "temizlik (K6)", "konfor (aydınlatma, havalandırma, rahatlık vb.) (K7)", "nezaket ve sayg (K8)", "işlem ve erişim kolaylığı (K9)" ve "hizmet çeşitliliği (K10)" şeklinde belirlenmiştir. Buradaki temel amaç, SERVQUAL, Lodgserv, Dineserv, SERVPERF gibi tüketicilerin hizmet kalitesi algısı üzerinde uygulanan klasik ve genel kabul gören yöntemler dışında, hizmet sunanların algısındaki kriterleri önem sırasına göre belirlemektir. 


\section{YÖNTEM}

\subsection{Araştırmanın Analizi}

Araştırmada AHS tekniği ile MAUT yöntemi kullanılmıştır. Bu yöntemler hizmet kalitesi kriterlerinin sıralamasının belirlenmesi ve en ideal hizmet kalitesi sunan otelin belirlenmesinde kullanılan çok kriterli karar verme yöntemleridir. Uzman görüşleri alınarak hizmet kalitesi kriterleri bu görüşlere göre AHS yöntemi ile sıralanmaktadır. Ardından MAUT yöntemi ile uzman görüşleri sonucu elde edilen verilere ve AHS hizmet kalitesi kriterleri değerlerine göre en ideal hizmet kalitesi sunan işletme belirlenmektedir.

\subsubsection{Analitik Hiyerarşi Süreci Tekniği}

AHS yönteminde izlenen adımlar aşağıdaki gibi özetlenebilir.

1. Adım Hiyerarşik Yapının Oluşturulması: Amaçlar, alternatifler ve kriterler bu adım içinde verilmektedir (Saaty, 2008, 85).

2. Adım Öncelikleri Belirlemek: Belirlenmiş olan kriterler arasındaki karşılaştırma matrisi, nxn boyutlu bir kare matris olarak ifade edilmetkedir. Saaty (1994) tarafından belirlenen, "1 - 9 ölçeği" ile önceliklendirme ölçeği hazırlanır ve anketler uzmanlara sunulur.

3. Adım Özvektörün (Göreli Önem Vektörünün) Tespiti: Belirlenen kriterlerin yüzdelik önem dağılımlarının belirlenmesi amacı ile, $n$ sayı ve bileşenli B sütun vektörü elde edilir. Aşağıdaki formül yardımı ile B sütun vektörü belirlenmektedir.

$$
b_{i j}=\frac{a_{i j}}{\sum_{i=1}^{n} a_{i j}}
$$

$n$ sayıda B sütun vektörünün, matris formatı şeklinde oluşturması ile $\mathrm{C}$ matrisi elde edilir. Bu matrisin örneği aşağıda gösterilmektedir.

$$
C=\left[\begin{array}{cccc}
c_{11} & c_{12} & \ldots & c_{1 n} \\
c_{21} & c_{22} & \ldots & c_{2 n} \\
\cdot & & & \cdot \\
\cdot & & & \cdot \\
\cdot & & & \cdot \\
c_{n 1} & c_{n 2} & \ldots & c_{n n}
\end{array}\right]
$$

C yardımı ile kriterler arasında birbirleri ile olan önem değerlerinin belirtildiği yüzdelik önem dağılımları elde edilir. C matrisini meydana getiren satır bileşenlerinin aritmetik ortalaması alınmaktadır. Öncelik Vektörü olan "W" sütun vektörü ortaya çıkmaktadır.

$$
w_{i}=\frac{\sum_{j=1}^{n} c_{i j}}{n}
$$

\section{Adım: Tutarlılık Oranının Hesaplanması}

AHS yönteminde, belirlenen Tutarlılık Oranı (CR) ile bulunmuş olan öncelik vektörü ve kriterlerin arasındaki birebir karşılaştırmaların tutarlılığı test edilmektedir. Saaty ve Özdemir (2003), bu kuralı detaylı bir şekilde belirtilmiştir. Tutarlılık oranının 0,10'den küçük olması gerekmektedir. CR hesaplamasının temelini, Temel Değer olarak belirtilen (๑) bir katsayısı ile kriter sayısının karşılaştııılması oluşturmaktadır. ๑’nın hesaplanması için ilk olarak, W öncelik vektörünün matrisi ile A karşılaştırma matrisinin çarpımı sonucunda D sütun vektörü elde edilmelidir. 
H. Akyurt - Ş. A. Demirdağ 11/4 (2019) 3131-3142

$$
D=\left[\begin{array}{cccc}
a_{11} & a_{12} & \ldots & a_{1 n} \\
a_{21} & a_{22} & \ldots & a_{2 n} \\
\cdot & & & \cdot \\
\cdot & & & \cdot \\
\cdot & & & \cdot \\
a_{n 1} & a_{n 2} & \ldots & a_{n n}
\end{array}\right] x\left[\begin{array}{c}
w_{1} \\
w_{2} \\
\cdot \\
\cdot \\
\cdot \\
w_{n}
\end{array}\right]
$$

Denklem (3)'de gösterildiği gibi, W sütun vektörü ile D sütun vektörünün elemanları karşllıklı olarak bölünerek, her bir değerlendirme kriteri ile ilgili temel değer (E) bulunmaktadır. Ortaya çıan değerlerin aritmetik ortalaması ise temel değeri $(\lambda)$ göstermektedir.

$$
\begin{gathered}
E_{i}=\frac{d_{i}}{w_{i}} i=1,2, \ldots, n \\
\lambda=\frac{\sum_{i=1}^{n} E_{i}}{n}
\end{gathered}
$$

“ $\lambda$ ” değerinin hesaplanması ile Tutarlılık Göstergesi (CI), Denklem (5) yardımı ile hesaplanır.

$$
C I=\frac{\lambda-n}{n-1}
$$

CI, Random Gösterge (RI) olarak ifade edilen standart düzeltme değerine bölünmesi ile CR değeri elde edilir. Bu değerin denklemi aşağıda gösterilmektedir.

$$
C R=\frac{C I}{R I}
$$

Elde edilen CR değerinin 0,10'den küçük çıkması, karar vericilerin kriterler hakkında karşılaştırmalarının tutarlı olduğunu ifade etmektedir. CR değerinin 0,10'den büyük olması ya AHS yönteminde meydana gelen hesaplamalarda hata olduğunu veya ankete cevap verenlerin yanıtlarında tutarsızlık olduğunu belirtmektedir.

\subsubsection{MAUT Tekniği}

MAUT tekniği, çok kriterli karar verme tekniklerinden biri olup, Fishburn (1967), Fishburn ve Keeney (1974) tarafından ortaya çıkarılan bir tekniktir. Løken (2007) tarafından geliştirilmiş olan bu teknik, daha sonraları karar verme konusundaki çalışmalarda uygulanmaya başlamıştır (Konuşkan ve Uygun, 2014: 1404). Bu tekniğin temel özelliği hem niceliksel hem de niteliksel kriterleri temel alarak en faydalı seçenekleri sunmasıdır. Bu teknikte sübjektif veriler hesaplanarak, en optimal seçeneğin araştırmacılar tarafından elde edilmesi sağlanabilmektedir (Løken ve Botterud, 2007: 1586-1587). MAUT tekniğinde uygulanan adımlar aşağıdaki gibidir (Ishizaka ve Nemery, 2012: 81-82; Konuşkan ve Uygun, 2014: 1405-1406).

1. Adım: Alternatiflerin ve Kriterler Ortaya Çıkarılması:

Karar probleminde bulunan kriterler (an) ve kriterlerin seçiminde yardımcı olan nitelikler veya kriterler (xm) tespit edilmektedir.

\section{Adım: Ağırlık Değerleri Tespiti:}

Elde edilen seçeneklerin doğru olarak değerlendirilmesi ve önceliklerin belirlenmesi için ağırlık değerlerinin (wj) atamaları yapılmaktadır. Bütün bu ağırlık (wj) değerleri toplamının 1'e eşit olması gerekmektedir.

$$
\text { (7) } \quad \sum_{i}^{m} w j=1
$$

3. Adım: Karar Matrisi Oluşturulması 
Tüm kriterlerin değer ölçüleri girilir. Bu verilerin girişinde nicel kriterleri bulmak için nicel değerler oluşturulur. Nitel kriterler için de ikili karşılaştırmalar ile değerlendirme yapılmaktadır. Bütün bu veriler ile 5’lik sistem, 100'lük sistem gibi değerler ile sisteme değer girişleri yapılmaktadır (xm).

\section{Adım: Normalize Edilen Fayda Değerinin Belirlenmesi}

Normalizasyon işlemi sırasında ilk olarak her bir nitelik için hem en iyi hem de en kötü değerler tespit edilir. En kötü değere 0, en iyi değeri 1 değeri, verilir. Farklı değerler ise aşağıdaki (8) formül ile hesaplanarak bulunur.

$$
\text { (8) } \quad f j(a i)=\frac{f i(a i)-\min (f i)}{\max (f i)-\min (f i)}
$$

\section{Adım: Toplam Fayda Değerlerinin Bulunması}

Normalizasyon işlemi sonrasında fayda değerlerinin ortaya çıkarılması işleminin yapılması gerekir. Fayda fonksiyonu aşağıda yer alan formüldeki (9) hesaplamalar ile yapılır.

(9) $U(a i)=\sum_{j=1}^{q} f i(a i) \cdot w j$

\subsection{Evren ve Örneklem}

Araştırmanın evreni, Ordu ili dört ve beş yıldızlı turizm işletme belgesine sahip oteller ile oluşturulmuştur. Ordu İl Kültür ve Turizm Müdürlügü̈'nün verilerine göre Ordu ili genelinde 7 adet turizm işletme belgesi olan dört ve beş yıldızlı otel bulunmaktadır (Ordu İl Kültür ve Turizm Müdürlüğü, 2019). Evreni temsil eden tüm otel yöneticilerine anket tekniği uygulanmıştır. Veri toplama tekniğinde ise söz konusu anketler, 9 uzman görüşünden yararlanılarak geliştirilmiştir.

Çok kriterli karar verme (ÇKKV) yöntemlerinin uygulanması diğer istatistiksel analizlerdeki gibi bir örneklem kütlesinden ana kütleye genelleme yapmak için kullanılan yöntemlerden değildir. ÇKKV yöntemleri, sübjektif ve objektif kriterlerin bir arada değerlendirildiği ve uzman görüşleri ile analizlerin gerçekleştirildiği yöntemlerdendir. Bu yöntemlerde bir grup konunun uzmanının kararına göre değerlendirmeler ve analizler yapılabileceği gibi tek bir uzman görüşü ile de analiz ve çalışmalar yapılabilmektedir (Korucuk vd., 219: 715). Bu nedenle AHS veya MAUT tekniği gibi çok kriterli karar verme yöntemlerinde örneklemin evreni temsil etmesi gibi bir durum söz konusu değildir. Yapılan bu çalışmada her ne kadar evrenin tamamına yönelik uygulama yapılmışsa da sonuçlar konusunda genelleme yapılmamalıdır.

\subsection{Veri Toplama Tekniği}

Araştırmada öncelikle anketler daha önce yapılmış olan çalışmalardan elde edilen hizmet kalitesi kriterlerine göre hazırlanmıştır. Hazırlanan anketler, Ordu ili otel yöneticileri ile yüz yüze görüşülerek uygulanmıştır. Dokuz otel yöneticisinden elde edilen anketlerin sonuçları AHS yönteminde Super Decision programı kullanılarak kriterlerin ağırlıklandırmaları yapılmıştır. Ardından MAUT yöntemi ile en ideal hizmet kalitesi kriterlerine sahip olan otel işletmelerinin belirlenmesi için analizler yapılmıştır. Araştırmada otel işletmelerinde sunulan hizmetlerin kalitesinde etkili olan 10 farklı kriter belirlenmiştir. Bu kriterler, Güven ve Çelik (2007) ile Korucuk vd., (2019) tarafından yapılan çalışmalarda da kullanılmış olan kriterlerdir. Çalışmada kullanılan hizmet kalitesi kriterleri Tablo 1'de verilmektedir.

Tablo 1. Hizmet Kalitesi Kriterleri

Kriterler
Fiyat K1
Güvenirlilik K2
Kat Hizmetleri Kalitesi K3
Ön Büro Hizmet Kalitesi K4
Restoran Hizmet Kalitesi K5
Temizlik K6
Konfor K7
Nezaket ve Sayg1 K8
İşlem ve Erişim Kolaylığ K9 9
Hizmet Çeşitliliği K10




\subsection{Araştırmanın Amacı ve Katkısı}

Yapılan bu araştırma, Ordu ilindeki dört ve beş yıldızlı otellerdeki hizmet kalitesi kriterlerinin önem derecesine göre sıralanması ve araştırma sonuçlarının işletmelerle paylaşılarak, iyileştirme - geliştirme politikalarına katkı sağlaması bakımından önemli bir çalışma olarak görülmektedir. Bir otel işletmesinin sunmuş olduğu hizmet kalitesi unsurları, turistlerin algılamalarında ve tercihlerinde doğrudan etkili olan en önemli faktörlerden biridir. Araştırma ile Ordu ili otel işletmelerinde yöneticilik yapan ve hedef kitleyi de oluşturan yöneticilerin görüşleri doğrultusunda hizmet kalitesi kriterleri önem derecesine göre sıralanmıştır. Bu kalite standartlarına göre en ideal hizmet kalitesi sunan otel belirlenmiştir. Hizmet kalitesi kriterleri her ülke, bölge veya otel açısından farklılık gösterebileceği gibi elde edilen bulgular sonucunda Ordu ilindeki otel işletmelerine hizmet kalitesi standartlarında dikkat etmeleri gereken unsurlar konusunda yardımcı olması beklenmektedir. Bununla birlikte, hizmet kalitesi kriterleri dikkate alınarak, otellerin hizmet kalitesi konusundaki anlayışlarının geliştirilmesi ve Ordu ili otellerine bilgi sağlaması konusunda faydalı olacağı düşünülmektedir.

\section{BULGULAR}

\subsection{AHS ile İlgili Bulgular}

Analizler sonucunda çok kriterli karar verme yöntemlerinden biri olan ve hizmet kalitesi kriterlerinin önem derecesine göre ağırlıklandırmasının yapıldığı AHS sonucu Tablo 2'de gösterilmektedir.

Tablo 2. Ana Kriterlere Ait Ağırlık Değerleri

\begin{tabular}{lllllllllll}
\hline K1 & K2 & K3 & K4 & K5 & K6 & K7 & K8 & K9 & K10 \\
\hline 0.039 & 0,117 & 0,056 & 0,067 & 0,040 & 0,283 & 0,025 & 0,245 & 0,107 & 0,021 \\
\hline
\end{tabular}

Tutarlılık Oranı: 0,08200

Analiz sonucunda anketin ve sonuçların tutarlılığını ölçen CR değeri 0,08200 çıkmıştır. Bu durum anketin ve ankete cevap veren otel işletmesi yöneticilerinin tutarlı cevaplar verdiği anlamına gelmektedir. CR değerinin 0,1'den küçük olması nedeniyle kriterlerin değerlendirilmesinde sorun olmadığı ve tutarlı sonuçlara ulaşıldığı anlaşılmaktadır. Yukarıdaki Tablo 2'de belirtilen kriterlerin ağırlıklandırılması sonucunda önem derecesine göre hizmet kalitesi kriterleri sıralanmaktadır. Hizmet kalitesi kriterlerinin Ordu ili otel işletme yöneticilerinin algıları ile sıralanması Tablo 3'te verilmektedir.

Tablo 3. Hizmet Kalitesi Kriterleri Önem Derecesi Sıralaması

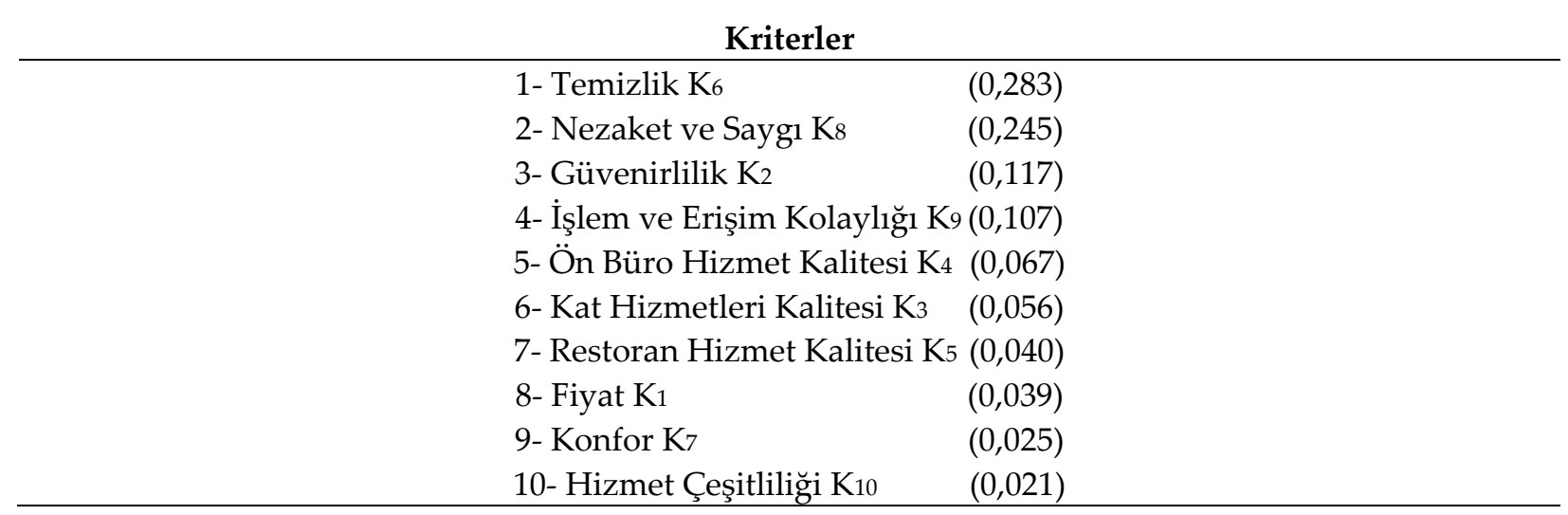

Tablo 3'te gösterilen sonuçlara göre Ordu ili otel yöneticileri açısından en önemli hizmet kalitesi kriterinin "Temizlik" olduğu tespit edilmiştir. Bununla birlikte, elde edilen oranlar doğrultusunda "Nezaket ve Saygı, Güvenirlilik, İşlem ve Erişim Kolaylığı" kriterlerinin de otel yöneticileri açısından hizmet kalitesinin en önemli kriterleri olduğu görülmektedir.

\subsection{MAUT Analizi Bulguları}

AHS sonuçlarının elde edilmesi ile MAUT tekniği için analizler yapılmıştır. Bu teknik, en ideal hizmet kalitesi sunan işletmenin belirlenmesini sağlamaktadır. Araştırmada, otel işletmelerinin isimlerinin belirtilmesi etik ilkeler gereği uygun olmayacağından dolayı verilmemektedir. 
MAUT analizinde ilk olarak anket verilerinde elde edilen tüm bilgiler matriste yerleştirilmiş ve aritmetik ortalama alınarak kriterler ile otel işletmelerini kapsayan karar vericilerin ortalanması matrisi oluşturulmuştur. Matriste " $K$ " değerleri hizmet kalitesi kriterlerini, " $A$ " değerleri ise sırası ile daha önce belirlenmiş olan dört ve beş yıldızlı otelleri temsil etmektedir. Karar vericilerin aritmetik ortalamasının belirlendiği matriste en büyük ve en küçük değerler belirlenmiştir. Bu matrisin boyutu çok büyük olduğu için çalışmada yer verilememektedir. Matriste en iyi değere sahip olanlara " 1 " değeri, en kötü değere sahip olan rakamlara ise " 0 " değeri verilmektedir. Diğer değerler ise aşağıdaki işlem kullanılarak belirlenmektedir.

$$
f j(a i)=\frac{f i(a i)-\min (f i)}{\max (f i)-\min (f i)}
$$

Bu sonuçlara göre elde edilen normalize edilmiş karar matrisi Tablo 4'te gösterilmektedir.

Tablo 4. Normalize Edilmiş Karar Matrisi

\begin{tabular}{lllllllllll}
\hline & K1 & K2 & K3 & K4 & K5 & K6 & K7 & K8 & K9 & K10 \\
\hline A1 & 0 & 1 & 0 & 0 & 0,5 & 1 & 0 & 0 & 0 & 0 \\
\hline A2 & 0 & 1 & 1 & 0,33 & 0,5 & 0 & 0 & 1 & 0 & 0 \\
\hline $\mathbf{A 3}$ & 1 & 1 & 1 & 0 & 0,5 & 0 & 0 & 0 & 0 & 0,5 \\
\hline $\mathbf{A 4}$ & 0 & 0 & 0 & 1 & 0 & 0 & 0 & 0 & 0,8 & 0,5 \\
\hline $\mathbf{A 6}$ & 0 & 1 & 0 & 0,66 & 1 & 1 & 0 & 1 & 1 & 0 \\
\hline $\mathbf{A 7}$ & 1 & 1 & 0 & 1 & 1 & 0 & 1 & 1 & 0,6 & 0,5 \\
\hline
\end{tabular}

Normalize edilmiş karar matrisinin yapılmasının ardından AHS sonuçlarında elde edilen hizmet kalitesi kriterleri ile tüm basamaklar tek tek çarpılarak normalize edilmiş toplam fayda değeri matrisi elde edilmektedir. Bu matris, karar verme matrisinin belirlenmesi için gerekli olan matristir. Bu sonuçlar Tablo 5'te gösterilmektedir.

Tablo 5. Normalize Edilmiş Toplam Fayda Değeri Matrisi

\begin{tabular}{lllllllllll}
\hline & K1 & K2 & K3 & K4 & K5 & K6 & K7 & K8 & K9 & K10 \\
\hline A1 & 0 & 0,117 & 0 & 0 & 0,02 & 0,283 & 0 & 0 & 0 & 0 \\
\hline A2 & 0 & 0,117 & 0,056 & 0,022 & 0,02 & 0 & 0 & 0,245 & 0 & 0 \\
\hline A3 & 0.039 & 0,117 & 0,056 & 0 & 0,02 & 0 & 0 & 0 & 0 & 0,011 \\
\hline A4 & 0 & 0 & 0 & 0,067 & 0 & 0 & 0 & 0 & 0,086 & 0,011 \\
\hline A5 & 0 & 0,117 & 0 & 0,044 & 0,040 & 0,283 & 0 & 0,245 & 0,107 & 0 \\
\hline A6 & 0.039 & 0,117 & 0 & 0,067 & 0,040 & 0 & 0,025 & 0,245 & 0,064 & 0,011 \\
\hline A7 & 0.039 & 0,117 & 0,056 & 0,067 & 0,040 & 0,283 & 0,025 & 0,245 & 0,107 & 0,021 \\
\hline
\end{tabular}

Normalize edilmiş toplam fayda değeri matrisinin elde edilmesi ile birlikte son aşama olan ve en ideal seçim karar matrisi oluşturulmaktadır. Bu matriste tüm " $\mathrm{K}$ ” değerleri toplanarak en ideal hizmet kalitesi sunan otel işletme sıralaması elde edilmektedir. Bu değerler Tablo 6' da gösterilmektedir. 
Tablo 6. En İdeal Seçim Karar Matrisi

\begin{tabular}{llcc}
\hline & $\mathbf{K} 1+\mathbf{K} 2+\mathbf{K} 3+\mathbf{K} 4+\mathbf{K} 5+\mathbf{K} 6+\mathbf{K} 7+\mathbf{K} 8+\mathbf{K} 9+\mathbf{K} 10$ & Toplam & En İdeal Otel Siralamasi \\
\hline A1 & $0+0,117+0+0+0,02+0,283+0+0+0+0$ & 0,420 & 5. \\
\hline A2 & $0+0,117+0,056+0,022+0,02+0+0+0,245+0+0$ & 0,460 & 4. \\
\hline A3 & $0.039+0,117+0,056+0+0,02+0+0+0+0+0,011$ & 0,243 & 6. \\
\hline A4 & $0+0+0+0,067+0+0+0+0+0,086+0,011$ & 0,164 & 7. \\
\hline A5 & $0+0,117+0+0,044+0,040+0,283+0+0,245+0,107+0$ & 0,836 & 2. \\
\hline A6 & $0.039+0,117+0+0,067+0,040+0+0,025+0,245+0,064+$ & 0,608 & 3. \\
\hline A7 & 0,011 & & $\mathbf{1 .}$ \\
\hline
\end{tabular}

MAUT tekniği analizi sonuçlarına göre Tablo 6' da elde edilen veriler 1şığında en ideal hizmet kalitesi sunan otel işletme sıralamasında, Ordu ilindeki 4 ve 5 yıldızlı oteller için A7 seçeneği en ideal otel olmuştur. Bununla birlikte, en ideal hizmet kalitesi sunan otellerin genel siralamas1 ise $A_{7}>A_{5}>A_{6}>A_{2} A_{1}>A_{3}>A_{4}$ olarak belirlenmiştir. Dolayısıyla, araştırma kapsamındaki otel işletmelerinin hizmet kalitesi algılarında en yüksek ortalamaya $(0,283)$ sahip olan hizmet kalitesi kriteri "temizlik" kriteri olarak belirlenmiştir. Diğer bir ifadeyle, otel işletmeleri yöneticileri öncelikli hizmet kalitesi kriterinin temizlik ve hijyen olduğu konusunda görüş bildirmiştir. Buna karşın, otel işletmeleri yöneticilerinin algısındaki en düşük ortalamaya $(0,021)$ sahip olan hizmet kalitesi kriteri ise "hizmet çeşitliliği" olarak tespit edilmiştir. Elde edilen bulgulara göre, otel işletmeleri yöneticileri tüketicilerine sunduğu hizmette temizlik ve hijyenden, tüketicilere karşı nazik ve hoşgörülü olmaktan, güvenilir otel imajı oluşturmaktan ve işlemlerde kolaylık sağlamaktan ödün vermeyeceği konusunda görüş bildirirken; hizmetleri çeşitlendirme, konfor ve fiyat gibi unsurların ise diğer kriterlere oranla hizmet kalitesi üzerinde çok etkili olmadığını ifade etmişlerdir.

\section{SONUÇ VE TARTIŞMA}

Bu çalışma, tüketiciler üzerinde uygulanan hizmet kalitesi çalışmalarından farklı olarak, otel yöneticileri algısında hizmet kalitesi kriterlerinden hangisinin daha önemli olduğu ortaya konmaya çalışılmıştır. Araştırma bulguları, Türkiye'de turizm sektöründeki hizmet kalitesiyle ilgili olarak turistler ve işletmeler üzerinde yapılan diğer çalışmaların sonuçları ile bazı benzerlikler göstermektedir. Öztürk ve Seyhan (2005) tarafından Antalya'da faaliyet gösteren beş yıldızlı oteller ve birinci sınıf tatil köylerinde konaklayan 416 yabancı turist üzerinde yapılan hizmet kalitesi (SERVQUAL) ile ilgili çalışmanın sonucuna göre, ilgili işletmelerde genel hizmet kalitesi düşük olarak hesaplanmıştır. Söz konusu işletmelerde diğer bölümlere kıyasen önbüro bölümü en yüksek hizmet kalitesi (Servqual) puanına $(-0,5132)$ sahipken, animasyon bölümü en düşük puana $(-0,8101)$ sahip olan bölüm olarak belirtilmiştir. Yapılan bu çalışmanın sonucunda da önbüro bölümünün hizmet kalitesi $(0,067)$ yöneticilerin algısına göre on kriter arasından önem sırasına göre beşinci sırada yer almaktadır. Murat ve Çelik (2007) tarafından AHS yöntemi ile Bartın ili merkezinde faaliyet gösteren üç yıldızlı üç otel üzerinde yapılan hizmet kalitesi çalışmasının sonucunda, en yüksek hizmet kalitesi ortalamasına $(0,5434)$ kat hizmetleri bölümü sahipken, önbüro bölümü daha düşük bir ortalamaya $(0,4566)$ sahiptir. Oysa bu çalışmanın sonucunda kat hizmetleri bölümünün hizmet kalitesi puanı $(0,056)$ diğer bölümlere oranla daha düşük hesaplanmış ve önem sırasında altıncı sırada yer almıştır. Eleren ve Kılıç (2007)'ın Afyonkarahisar'da faaliyet gösteren bir termal otel işletmesinde SERVQUAL tekniği kullanarak 125 katılımcı ile gerçekleştirdiği çalışmada fiziksel özellikler, güvenilirlik ve heveslilik başta olmak üzere tüm kriterlerin hizmet kalitesi puanları düşük olarak hesaplanmıştır. Bu çalışmada ise temizlik, hijyen ve güvenilirlik boyutlarındaki yönetici hizmet kalitesi algısı daha yüksek oranlarda hesaplanmıştır. Avcı ve Sayılır (2006)'in hizmet kalitesi kapsamında personelin rolü ve yeterliliklerine yönelik Muğla'da faaliyet gösteren 39 işletmede konaklayan 263 turist ve 78 personel üzerinde anket tekniği uygulayarak gerçekleştirdikleri çalışmada, çalışanların mesleki uzmanlıkları, bilgi düzeyleri ve iletişim konusundaki yeterliliklerinin düşük seviyede olduğu, problemleri çözme yeterliliklerinin ise kısmen yeterli seviyede olduğu, turistlere karşı tutum ve davranışlarının ise oldukça yeterli bir seviyede olduğu sonucuna ulaşılmıştır. 
Benzer bir şekilde bu çalışmada da tüketicilere karşı nezaket ve saygı $(0,245)$, güvenilir olma $(0,117)$ ve işlemerişim kolaylığı $(0,107)$ hizmet kalitesi kriterleri yüksek oranda bulunmuştur.

Hizmet kalitesi ve toplam kalite yönetiminin günümüz işletmeleri açısından önemli kavramlar olduğu yadsınamaz bir gerçektir. Özellikle hem ürün hem de hizmet sunumu yapan otel işletmeleri açısından hizmet kalitesi standartları doğrudan talebe etki etmektedir. Bu bakımdan bir otel işletmesinin turistik talebi çekebilmesi ve sürdürülebilir hale getirebilmesi için hizmet kalitesi standartlarına önem vermesi gerekmektedir. Özellikle turizm işletme belgeli ve yıldız sahibi olan otel işletmeleri açısından hizmet kalitesine sahip olmak önemli bir imaj unsurudur. Dolayısıyla, otel işletmesinin mevcut ve potansiyel müşterileri açısından hizmet kalitesinin sunumu önem arz etmektedir.

Araştırmada hizmet kalitesi kriterleri arasında en önemli kriterin temizlik kriteri olduğu tespit edilmiştir. Ordu ili otel yöneticilerinin görüşlerine dayanarak elde edilen bu bulgu, yöneticilerin özellikle işletmelerinde temizliği hizmet kalitesinin vazgeçilmez unsuru olarak gördüklerini göstermektedir. Bununla birlikte, diğer en önemli hizmet kalitesi kriterinin işletmede müşterilere ya da turistlere sunulan nezaket ve saygı olduğu belirlenmiştir. Ayrıca, otelin güvenilirliği ve işlemlerde turistlere sağlanan kolaylıklar da hizmet kalitesinin önemli kriterleri olarak tespit edilmiştir. Araştırmada fiyat, konfor ve hizmet çeşitliliğinin en düşük derecede önemli hizmet kalitesi kriterleri olduğu da diğer dikkat çekici bir bulgu olarak dikkat çekmektedir. Otel yöneticileri tarafından fiyatların, konforun ve hizmet çeşitliliğinin otel işletmeleri için önemli birer hizmet kalitesi kriterleri olmadığı belirtilmiştir. Elde edilen bu bulgular, otel işletmeleri yöneticilerinin algısındaki hizmet kriterleri olduğu için diğer işletmeler ya da akademik çalışmalarla ilişkilendirilmemeli ve genelleştirilememelidir.

Araştırmada Ordu ili dört ve beş yıldızlı oteller içinde en ideal hizmet kalitesi sunan otel işletmesinin belirlendiği bulgular elde edilmiştir. Etik kurallar gereği bu otellerin araştırmada belirtilememesine rağmen, otel yöneticileri ile bu sonuçların paylaşılması planlanmaktadır. Bu sayede, Ordu ilindeki otel işletmeleri yöneticilerinin bilimsel olarak elde edilen bu bilgiler doğrultusunda hizmet kalitesi ile ilgili daha özverili çalışmalar yapabilecekleri ve bu konuda iyileştirme-geliştirme çalışmaları gerçekleştirebilecekleri düşünülmektedir. Ordu ili otellerinde hizmet kalitesini arttırmak isteyen otel yöneticilerinin öncelikle otelin genel temizliği konusunda işletmelerini geliştirmeleri gerektiği önerilebilir. Bununla birlikte, otel içinde turistlere karşı sergilenen nezaket ve saygı durumunun da etkili bir kriter olması nedeniyle, işetme için alınacak personelin bu konuda eğitilmesi ya da nitelikli personel seçilmesinin uygun olacağı söylenebilir. Ordu ili otel işletme yöneticilerinin hizmet kalitesi kriterlerinden hangilerinin daha önemli olduğunu öğrenmeleri, işletmelerinde uyguladıkları hizmet kalitesi standartlarını geliştirmeleri bakımından da önem arz etmektedir. Bu çalışmada elde edilen veriler sonucunda, yöneticilerin otellerindeki hizmet kalitesi kriterlerini gözden geçirerek, turistler açısından en uygun hizmet kalitesi anlayışını belirlemeleri beklenmektedir. Ayrıca bu çalışmanın otel işletmelerinde hizmet kalitesi konusunda çalışma yapan ve çok kriterli karar verme yöntemlerini uygulamayı düşünen akademisyenler ve bilim insanları için yol gösterici nitelikte olacağı düşünülmektedir.

\section{KAYNAKLAR}

Aksoy, R. (2005). Zonguldak'ta ayakta tedavi tüketicilerinin sağlık hizmeti kalite değerlemesi, Zonguldak Karaelmas Üniversitesi Sosyal Bilimler Dergisi, 1(1): 91-104.

Avcı, U. ve Sayılır, A. (2006). Hizmet kalitesi çerçevesinde çalışanların rolüne ve yeterliliklerine ilişkin karşılaştırmalı bir inceleme karşılaştırmalı bir inceleme, Ticaret ve Turizm Eğitim Fakültesi Dergisi, 2006(1), 121-138.

Çiçek, R. ve Doğan, İ. C. (2009). Müşteri memnuniyetinin artırılmasında hizmet kalitesinin ölçülmesine yönelik bir araştırma: Niğde ili örneği, Afyon Kocatepe Üniversitesi İ.I.B.F. Dergisi, 11(1): 199-217.

Devebakan, N. ve Aksaraylı, M. (2003). Sağlık işletmelerinde algılanan hizmet kalitesinin ölçümünde SERVQUAL skorlarının kullanımı ve Özel Altınordu Hastanesi uygulaması, Dokuz Eylül Üniversitesi Sosyal Bilimler Enstitüsü Dergisi, 5(1): 38-54. 
Eleren, A., Bektaş, Ç. ve Görmüş, A. Ş. (2007). Hizmet sektöründe hizmet kalitesinin SERVQUAL yöntemi ile ölçülmesi ve hazır yemek işletmesinde bir uygulama, Finans Politik \& Ekonomik Yorumlar, 44(514), 7588 .

Eleren, A. ve Kılıç, B. (2007). Turizm sektöründe SERVQUAL analizi ile hizmet kalitesinin ölçülmesi ve bir termal otelde uygulama, Afyon Kocatepe Üniversitesi İ.I.B.F. Dergisi, 9(1), 235-263.

Fishburn, P. C. (1967). Conjoint measurement in utility theory with incomplete product sets, Journal of Mathematical Psychology, 4(1), 104-119.

Fishburn, P. C. and Keeney, R. L. (1974). Seven independence concepts and continuous multiattribute utility functions, Journal of Mathematical Psychology, 11(3), 294-327.

Gržinić, J. (2007). Concepts of service quality measurement in hotel industry, Ekon. Misao Praksa Dbk. God., 16(1): 81-98.

Güçer, E., Silik, C. E. ve Demirdağ, Ş. A. (2017). Turistlerin animasyon hizmetlerine yönelik kalite algılamalarının belirlenmesi: Beş yıldızlı oteller üzerine bir çalışma, İçinde: Bilici, N., Pehlivanlı, R. ve Ashirkhanova, Karlygash (eds.), Innovation and Global Issues in Social Sciences Congress Book. April 2729, 2017, Antalya. Antalya, Inglobe Platform, 454-473.

Güven, M. ve Çelik N. (2007). Analitik hiyerarşi süreci yöntemi ile otel işletmelerinde hizmet kalitesini değerlendirme: Bartın örneği, ZKÜ Sosyal Bilimler Dergisi, 3 (6): 1-20.

Halis, M. (2010). Toplam kalite yönetiminin temel kavramları, Demirkol, Ş. ve Halis, M. (ed.), Turizm işletmelerinde toplam kalite yönetimi, İstanbul, Değişim Yayınları, 1-36.

Halis, M., Oğuz, T. ve Akova, O. (2010). Turizm sektörü için toplam kalite yönetimi, Demirkol, Ş. ve Halis, M. (ed.), Turizm işletmelerinde toplam kalite yönetimi, İstanbul, Değişim Yayınları, 37-108.

Hernon, P. and Nitecki, D. A. (2001). Service quality: a concept not fully explored, Library Trends, 49(4): 687708.

Ishizaka, A. and Nemery, P. (2013). Multi-criteria decision analysis: methods and software, Chichester / UK: John Wiley \& Sons Ltd. Published.

Karafakığlu, M. (1998), Sağlık hizmetleri pazarlaması, İstanbul: İşletme Fakültesi Yayınları.

Kılıç, B. ve Eleren, A. (2009). Turizm sektöründe hizmet kalitesi ölçümü üzerine bir literatür araştırması, Alanya İşletme Fakültesi Dergisi, 1(1): 91-118.

Konuşkan, Ö. ve Uygun, Ö. (2014). Çok nitelikli karar verme (MAUT) yöntemi ve bir uygulaması, ISITES 2014, 1403-1412.

Korucuk, S., Akyurt, H. ve Turpcu, E. (2019). Otel işletmelerinde hizmet kalitesinin Entropi yöntemi ile ölçülmesi: Giresun ilindeki üç yıldızlı oteller üzerine bir araştırma, Manas Sosyal Araştırmalar Dergisi, 8(1/1), 709-721.

Kuriloff, A. H. and Hemphill, J. M. (1988). Starting and managing the small business, (2nd editon), New York, McGraw-Hill Inc.

Løken, E. (2007). Use of multicriteria decision analysis methods for energy planning problems. Renewable and Sustainable Energy Reviews, 11(7), 1584-1595.

Løken E. and Botterud A. (2007). Planning of mixed local energy distribution systems: A comparison of two multi-criteria decision methods, 28th Annual IAEE International Conference, Taipei, Taiwan, 1586-1587.

Murat, G. ve Çelik, N. (2007). Analitik hiyerarşi süreci yöntemi ile otel işletmelerinde hizmet kalitesini değerlendirme: Bartın örneği, ZKÜ Sosyal Bilimler Dergisi, 3(6), 1-20.

Okumuş, A. ve Duygun, A. (2008). Eğitim hizmetlerinin pazarlanmasında hizmet kalitesinin ölçümü ve algılanan hizmet kalitesi ile öğrenci memnuniyeti arasındaki ilişki, Anadolu Üniversitesi Sosyal Bilimler Dergisi, 8(2): 17-38.

Oral, S. (1999). Otel işletmeciliği ve otel işletmelerinde verimlilik analizleri, İzmir, Kanyılmaz Matbaası. 
H. Akyurt - Ş. A. Demirdağ 11/4 (2019) 3131-3142

Ordu İl Kültür ve Turizm Müdürlüğü. (2019). Ordu İli Turizm İşletme Belgeli Tesis Sayıs1. http://www.ordu.gov.tr/turizm-isletme-belgeli-tesisler (Erişim Tarihi:15.10.2019).

Öztürk, Y. ve Seyhan, K. (2005). Konaklama işletmelerinde sunulan hizmet kalitesinin Servqual yöntemi ile ölçülmesi, Anatolia: Turizm Araştırmaları Dergisi, 16(2), 170-182.

Parasuraman, A., Zeithaml, V. and Berry, L. L. (1985), A conceptual model of service quality and its implications for future research, Journal of Marketing, 49(1): 41-50.

Parasuraman, A., Zeithaml, V. A. and Berry, L. L. (1988). SERVQUAL: A multiple - item scale for measuring consumer perception of service quality, Journal of Retailing, 64(1): 12-40.

Saaty T.L. (1994). How to make a decision: the analytic hierarchy process. Interfaces, 24(6): 19-43.

Saaty, T.L. (2008). Decision making with the analytic hierarchy process, International Journal of Services Sciences, 1(1): 83-98.

Saaty, T. L. and Özdemir, M. (2003), Negative priorities in the analytic hierarchy process, Mathematical and Computer Modeling, 37(910): 1063-1075.

Tavmergen, I. P. (2002). Turizm sektöründe kalite yönetimi: hizmet kalitesi kavramı-kalite yaklaşımları ve kalite geliştirme-toplam kalite yönetimi-kullanılan araçlar ve teknikler, Ankara, Seçkin Yayıncılık.

Üzerem, N. (1997). Hizmet kalitesinin yönetimi, Pazarlama Dünyası Dergisi, 11(63): 34-41.

Zeithaml, V. A., Parasuraman, A. and Berry, L. L. (1990). Delivering quality service: Balancing customer perceptions and expectation, USA: Free Press. 